\title{
Regulation of Cation Content and Cell Volume in Hemoglobin Erythrocytes from Patients with Homozygous Hemoglobin C Disease
}

Carlo Brugnara, Alan S. Kopin, H. Franklin Bunn, and Daniel C. Tosteson

Department of Physiology and Biophysics, Harvard Medical School, Boston, Massachusetts 02115; Laboratory of the Howard Hughes

Medical Institute, Hematology Division, Brigham and Women's Hospital, Harvard Medical School, Boston, Massachusetts 02115

\begin{abstract}
Erythrocytes from patients with homozygous hemoglobin $\mathrm{C}$ disease ( $\mathrm{CC}$ cells) contain less $\mathrm{K}, \mathrm{Na}$, and water than do erythrocytes from normal subjects that contain only hemoglobin A (AA cells). In this paper, we provide evidence that the reduced $\mathrm{K}$ content and volume of $\mathrm{CC}$ cells are due to the activity in these but not in $A A$ cells of a $K$ transport system that is: (a) insensitive to ouabain and bumetanide, and (b) stimulated by increased cell volume, and dependent on internal $\mathrm{pH}\left(\mathrm{pH}_{\mathrm{i}}\right)$. When the cation and water content of $\mathrm{CC}$ cells was increased (by making the membrane temporarily permeable to cations with nystatin) and the cells were then incubated in an isotonic medium containing $140 \mathrm{mM} \mathrm{NaCl}$ and $4 \mathrm{mM} \mathrm{KCl}$, they lost $K$ and shrunk back toward the original volume. This regulatory $K$ and volume decrease was not inhibited by ouabain or bumetanide. When $\mathrm{CC}$ cells were incubated in a hypotonic medium, with ouabain and bumetanide, they also lost $K$ and shrunk toward the original volume. This behavior was not observed in control AA cells. The ouabain- and bumetanideresistant $\mathrm{K}$ efflux from $\mathrm{CC}$ cells was volume and $\mathrm{pH}$ dependent: $K$ efflux from CC cells rose from 5-6 to $20-25 \mathrm{mmol} / \mathrm{liter}$ of cells $\times h$, when cell volume was increased by increasing cell solute content (nystatin method) or by exposure to hypotonic media. In $\mathrm{CC}$ cells, the dependence of $\mathrm{K}$ efflux on $\mathrm{pH}_{\mathrm{o}}$ had a bell shape, with a maximal flux (20-25 mmol/liter of cells $\times$ h) at $\mathrm{pH}_{\mathrm{o}}$ 6.8-7.0. In contrast, the $\mathrm{K}$ efflux from control cells was minimal at pH $7.4(1.2 \mathrm{mmol} / \mathrm{liter}$ of cells $\times h)$ and was slightly stimulated by both acid and alkaline $\mathrm{pH}$. In order to study the effect of $\mathrm{pH}_{\mathrm{i}}$ and $\mathrm{pH}_{\mathrm{o}}$ on $\mathrm{K}$ efflux, $\mathrm{CC}$ cells were incubated with 4,4'-diisothiocyanostilbene-2,2'-disulfonic acid $(150 \mu \mathrm{M})$ and acetazolamide $(1 \mathrm{mM})$ at different $\mathrm{pH}_{\mathrm{i}}(6.7,7.3$, and 7.8), and resuspended in media with different $\mathrm{pH}_{\mathrm{o}}(6.75$, 7.4, and 8): $\mathrm{K}$ efflux was stimulated by reducing $\mathrm{pH}_{\mathrm{i}}$ but was independent of $\mathrm{pH}_{\mathrm{o}}$. The ouabain- and bumetanide-resistant $\mathrm{K}$ efflux from $\mathrm{CC}$ cells was not inhibited by some inhibitors of the $\mathrm{Ca}^{2+}$-activated $\mathrm{K}$ permeability. It seems likely that the genetically determined change in the primary structure of hemoglobin $\mathrm{C}$ directly or indirectly causes this modification in $K$ transport. One possible mechanism could involve an electrostatic interaction between $C$ hemoglobin and components of the erythrocyte membrane.
\end{abstract}

An abstract of this work was presented at the 97th Meeting of the Association of American Physicians in 1984 and at the 38th Annual Meeting of the Society of General Physiologists in 1984.

Address correspondence and reprint requests to Dr. Brugnara.

Received for publication 26 September 1984 and in revised form 7 January 1985.

J. Clin. Invest.

(C) The American Society for Clinical Investigation, Inc.

$0021-9738 / 85 / 05 / 1608 / 10 \quad \$ 1.00$

Volume 75 , May $1985,1608-1617$

\section{Introduction}

The difference between hemoglobin $\mathrm{C}$ and hemoglobin $\mathrm{A}$ involves a single base substitution in the $\beta 6$-codon, leading to a replacement of glutamate by lysine (1). Because, at a given $\mathrm{pH}$, the net negative charge on hemoglobin is reduced in CC erythrocytes (cells from patients with homozygous hemoglobin $\mathrm{C}$ disease) as compared to AA erythrocytes (normal subject cells containing only hemoglobin $\mathrm{A}$ ), one would expect the chloride ratio $\left(\left[\mathrm{Cl}_{\mathrm{i}}\right] /\left[\mathrm{Cl}_{0}\right]\right)$ to be higher, if the cation content of $\mathrm{CC}$ and AA cells were the same. However, Murphy $(2,3)$ reported that the cation and water content of $\mathrm{CC}$ cells is reduced, but did not investigate how cation transport in CC cells produces this reduced cation and water content. The experiments described in this paper were designed to answer that question.

We recently found (4) that the cell isoelectric point is higher (7.15 vs. 6.95$)$, and the absolute charge of the impermeant erythrocyte solutes is lower $(-10 \mathrm{vs}$. $-50 \mathrm{meq} / \mathrm{kg}$ of dry cell solids) in CC than in AA cells. This difference of 40 $\mathrm{meq} / \mathrm{kg}$ of dry cell solids in the charge of impermeant cell solutes accounts for +3 change in the charge of each hemoglobin molecule compared to the +4 expected. We attributed this difference to changes in other nonpermeant solutes, such as 2,3-diphosphoglyceric acid (2,3-DPG). ${ }^{1}$ A greater reduction was found in the total cation content $(212$ vs. $265 \mathrm{mmol} / \mathrm{kg}$ of dry cell solids). In contrast to previous reports $(2,3)$, we found that the $\mathrm{Cl}^{-}$distribution ratio (and therefore membrane potential and internal $\mathrm{pH}$ ) is the same in $\mathrm{CC}$ and $\mathrm{AA}$ erythrocytes.

In this paper we examine the transport pathways for $\mathrm{Na}$ and $\mathrm{K}$ in $\mathrm{CC}$ erythrocytes. We show that $\mathrm{CC}$ cells regulate their volume through a ouabain- and bumetanide-insensitive pathway for $\mathrm{K}$. This pathway seems to be responsible for the reduction in $\mathrm{K}$ and water content observed in $\mathrm{CC}$ cells. The pathway is dependent on cell volume and internal $\mathrm{pH}$, and does not share any of the properties of the Ca-activated $\mathrm{K}$ transport system first described by Gardos (for a review see reference 5).

A preliminary report of this work has previously appeared in another publication (6).

\section{Methods}

Preparation of erythrocytes. Blood was collected in heparinized Vacutainer tubes (Becton, Dickinson \& Co., Rutherford, NJ) from two

1. Abbreviations used in this paper: AA cells, normal erythrocytes that contain only hemoglobin A; CC cells, erythrocytes from patients with homozygous hemoglobin $C$ disease; DIDS, 4,4'-diisothiocyanostilbene2,2'-disulfonic acid; 2,3-DPG, 2,3-diphosphoglyceric acid; MCHC, mean corpuscular hemoglobin concentration; MOPS, 3- $(N$-morpholino)propanesulfonic acid; $\mathrm{OB}$, ouabain and bumetanide. 
donors homozygous for hemoglobin $\mathrm{C}$ (CC cells) and three normal controls (AA cells). The blood was centrifuged in a Sorvall centrifuge (RB 5B, DuPont Instruments, Sorvall Biomedical Div., Newtown, CT) at $5^{\circ} \mathrm{C}$ for $10 \mathrm{~min}$ at $3,000 \mathrm{~g}$. Plasma and buffy coat were carefully removed and the cells were washed four times with a washing solution containing $152 \mathrm{mM}$ choline chloride, $1 \mathrm{mM} \mathrm{MgCl}, 10 \mathrm{mM}$ Tris-MOPS [tris(hydroxymethyl)aminomethane-3-( $N$-morpholino)prosulfonic acid], $\mathrm{pH} 7.4$, at $4^{\circ} \mathrm{C}$. An aliquot of cells was then suspended in an approximately equal volume of choline washing solution, and from this cell suspension determination of hematocrit (Hct), cell $\mathrm{Na}$ (1:50 dilution in $0.02 \%$ Acationox, American Scientific Products, McGaw Park, IL), cell K (1:500 dilution), hemoglobin (optical density at $540 \mathrm{~nm}$ in Drabkin's solution), and mean corpuscular hemoglobin concentration (MCHC) were carried out. The erythrocyte $\mathrm{Na}$ and $\mathrm{K}$ content was determined in a Perkin-Elmer atomic absorption spectrophotometer (model 5000, Perkin-Elmer Corp., Norwalk, CT) using standards in double-distilled water. Dry weight and ${ }^{36} \mathrm{Cl}$ distribution ratio were measured in whole blood and washed cells according to Freedman and Hoffman (7).

When the experiments were not performed on the same day of collection, the erythrocytes were stored at $4^{\circ} \mathrm{C}(20 \%$ hematocrit $)$ in a preservation solution containing $140 \mathrm{mM} \mathrm{KCl}, 10 \mathrm{mM} \mathrm{NaCl}, 1 \mathrm{mM}$ $\mathrm{MgCl}_{2}, 2.5 \mathrm{mM} \mathrm{NaH} \mathrm{PO}_{4}$ buffer, $\mathrm{pH} 7.4$, and $10 \mathrm{mM}$ glucose. All experiments were performed within $2 \mathrm{~d}$ of sampling.

Measurement of $K$ efflux from fresh cells. $\mathrm{K}$ efflux from CC cells and controls was measured into $\mathrm{Na}$ or choline medium, as a function of external $\mathrm{pH}\left(\mathrm{pH}_{\mathrm{o}}\right)$, at constant osmolarity (295-300 mosM), and as a function of osmolarity, at constant $\mathrm{pH}_{\mathrm{o}}$ (7.4). When the $\mathrm{pH}_{\mathrm{o}}$ was varied, the medium contained $140 \mathrm{mM} \mathrm{NaCl}$, (or $140 \mathrm{mM}$ choline chloride), $1 \mathrm{mM} \mathrm{MgCl}, 10 \mathrm{mM}$ glucóse, $0.1 \mathrm{mM}$ ouabain, $0.01 \mathrm{mM}$ bumetanide, and $10 \mathrm{mM}$ Tris-MOPS, $\mathrm{pH} 6.2-8.0$, at $37^{\circ} \mathrm{C}$. When the osmolarity was varied, the medium contained $100 \mathrm{mM} \mathrm{NaCl}$ (or 100

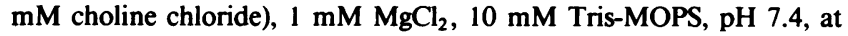
$37^{\circ} \mathrm{C}, 10 \mathrm{mM}$ glucose, $0.1 \mathrm{mM}$ ouabain, and $0.01 \mathrm{mM}$ bumetanide. The osmolarity was varied from 220 to 400 mosM by adding choline chloride. For the flux assay, $0.4 \mathrm{ml}$ of cell suspension in choline washing solution (hematocrit $30 \%$ ) was added to $9 \mathrm{ml}$ of flux medium, and this flux suspension was then distributed into six previously chilled 5-ml tubes. After capping, three tubes were incubated for $5 \mathrm{~min}$ and three for $25 \mathrm{~min}$ in a shaking water bath at $37^{\circ} \mathrm{C}$. The time course of $\mathrm{K}$ efflux into hypotonic, isotonic, and hypertonic media was determined in preliminary experiments. A 25-min incubation was chosen in order to meet conditions of linear initial rate in the flux measurement. At the end of the incubation, the tubes were transferred to an ice bath and, after $2 \mathrm{~min}$, they were spun at $3,000 \mathrm{~g}$ for $5 \mathrm{~min}$. The supernatant was removed and the $K$ concentration was measured by atomic absorption using standards for $\mathrm{K}$ with the same composition of the flux medium.

Measurement of unidirectional radioactive influx in fresh cells. 9 $\mathrm{ml}$ of medium was chilled and mixed with $10 \mu \mathrm{Ci}$ of ${ }^{22} \mathrm{Na}$, or $30 \mu \mathrm{Ci}$ of ${ }^{86} \mathrm{Rb}\left({ }^{86} \mathrm{Rb}\right.$ was used as a tracer for $\mathrm{K}$ fluxes). The radioactivity in five aliquots of $20 \mu \mathrm{l}$ of medium was measured for determination of initial specific activity. $0.5 \mathrm{ml}$ of packed red cells was added to the medium. The flux suspension was then distributed into six previously chilled 5- $\mathrm{ml}$ tubes, and after capping the tubes were incubated in a water bath at $37^{\circ} \mathrm{C}$, under shaking. The supernatant of the samples, collected after 5 and $25 \mathrm{~min}$ of incubation at $37^{\circ} \mathrm{C}$, was discarded and the cells were washed three times with $4 \mathrm{ml}$ of cold $\mathrm{Na}$ washing solution containing $150 \mathrm{mM} \mathrm{NaCl}, 1 \mathrm{mM} \mathrm{MgCl}$, and $10 \mathrm{mM}$ TrisMOPS, pH 7.4, at $4^{\circ} \mathrm{C}$. Afterwards, the cell pellet was lysed with $1 \mathrm{ml}$ of double-distilled water containing $0.02 \%$ Acationox (American Scientific Products). The tubes were vortexed and spun for $20 \mathrm{~min}$ at $3,000 \mathrm{~g}$. Aliquots of $50 \mu \mathrm{l}$ were diluted 50 times with an automatic dilutor, and the concentration of hemoglobin was determined at 540 $\mathrm{nm}$. Aliquots of $0.8 \mathrm{ml}$ of the lysate were counted in a gamma counter (Auto-Gamma 500, Packard Instrument Co., Lynn, MA).

The influx in millimoles/liter of cells $\times$ hour was calculated from influx $=$ counts per minute/liter of erythrocytes $(25 \mathrm{~min}-5 \mathrm{~min}$ of incubation)/initial specific activity (counts per minute/millimole) 60 $\mathrm{min} / 20 \mathrm{~min}$, where counts per minute/liter of erythrocytes = counts per minute in the lysate $\times 1 / \mathrm{Vl} \times 100 / \mathrm{Hct}$, where $\mathrm{Vl}$ is the volume (liters) of lysate counted and hematocrit is the amount of cells (\%) in the lysate. The quantity of erythrocytes present in the lysate was calculated using the hematocrit and concentration of hemoglobin of the initial cell suspension, and the concentration of hemoglobin determined in the lysate.

Nystatin-loading procedure. The procedure developed by Canessa et al. (8) was used. The loading solution contained $140 \mathrm{mM}$ cations and $20-100 \mathrm{mM}$ sucrose. The $\mathrm{Na}$ and $\mathrm{K}$ concentrations in the loading solution were reciprocally changed according to the desired cell $\mathrm{Na}$ and $\mathrm{K}$ content (e.g., $10 \mathrm{mM} \mathrm{NaCl}$ and $130 \mathrm{mM} \mathrm{KCl}$, to yield $7 \mathrm{mmol} /$ liter of cell $\mathrm{Na}$ and $90 \mathrm{mmol} / \mathrm{liter}$ of cell $\mathrm{K}$ ). The sucrose concentration in the loading solution varied from 20 to $100 \mathrm{mM}$ according to the desired cell volume. In the presence of nystatin, cell volume is set by the concentration of nonpermeant solutes in the external solution (7). Erythrocyte water contents similar to those measured in plasma were obtained with $70 \mathrm{mM}$ sucrose (CC cells) and $55-60 \mathrm{mM}$ sucrose (AA cells). Sucrose concentrations below or above these values, resulted in swollen or shrunken cells as desired. $1 \mathrm{ml}$ of choline-washed cells was added to $5 \mathrm{ml}$ of cold loading solution, containing $40 \mu \mathrm{g} / \mathrm{ml}$ of nystatin. The nystatin was dissolved fresh every day in dimethyl sulfoxide $(5 \mathrm{mg}$ in $0.25 \mathrm{ml})$. The cell suspension was incubated at $4^{\circ} \mathrm{C}$ for $20 \mathrm{~min}$ and vortexed every $5 \mathrm{~min}$. The cold suspension was then centrifuged for $5 \mathrm{~min}$ at $2,000 \mathrm{~g}$ and the supernatant removed. The cells were incubated again in a larger volume $(20-30 \mathrm{ml})$ of cold loading solution without nystatin. This procedure allows complete equilibration of the cell cation content with the loading solution. When measurements of unidirectional radioactive $\mathrm{Na}$ or $\mathrm{K}$ efflux were performed, the cells were incubated a final time with $1 \mathrm{ml}$ of cold loading solution containing $5 \mu \mathrm{Ci}^{22} \mathrm{Na}$ or $50 \mu \mathrm{Ci}{ }^{86} \mathrm{Rb}$. The cells were then washed four times with a warm $\left(37^{\circ} \mathrm{C}\right)$ solution having the same composition as the loading solution, with the addition of $1 \mathrm{mM} \mathrm{Na}$ or $\mathrm{K}$ phosphate buffer, $\mathrm{pH} 7.4,10 \mathrm{mM}$ glucose, and $0.1 \%$ albumin. Afterwards, the cells were washed five times at $4^{\circ} \mathrm{C}$ with choline washing solution and used for efflux or influx measurement. An aliquot of cells was used to measure hematocrit, cell $\mathrm{Na}$ and $\mathrm{K}$, hemoglobin and MCHC, and dry weight.

Measurement of maximal rates of Na-K pump, Na-K cotransport, and Na-Li countertransport. To assay the maximal rate of $\mathrm{Na}-\mathrm{K}$ pump and $\mathrm{Na}-\mathrm{K}$ cotransport, the red cells were made to contain equal amounts of $\mathrm{Na}$ and $\mathrm{K}(50 \mathrm{mmol} / \mathrm{liter}$ of cells each). This procedure allows saturation of the internal sites for both transport systems. The nystatin-loading solution contained $70 \mathrm{mM} \mathrm{NaCl}, 70 \mathrm{mM} \mathrm{KCl}$, and $65 \mathrm{mM}$ sucrose for CC cells or $55 \mathrm{mM}$ sucrose for AA cells. The Na$\mathrm{K}$ pump was estimated as the ouabain-sensitive fraction of the $\mathrm{Na}$ efflux into a medium containing $130 \mathrm{mM}$ choline chloride and 10 $\mathrm{mM} \mathrm{KCl}$. The incubation times were 5 and $25 \mathrm{~min}$ at $37^{\circ} \mathrm{C}$, with triplicate samples. The hematocrit of the efflux cell suspension was $1 \%$. The Na-K cotransport was estimated as the furosemide or bumetanide sensitive fraction of the $\mathrm{Na}$ and $\mathrm{K}$ efflux into a medium containing $140 \mathrm{mM}$ choline chloride and $0.1 \mathrm{mM}$ ouabain. The efflux times were 5 and $25 \mathrm{~min}$, with triplicate samples. The hematocrit of the efflux cell suspension was $2 \%$. To assay the maximal rate of the $\mathrm{Na}-\mathrm{Li}$ countertransport, the nystatin-loading solution contained 10 $\mathrm{mM} \mathrm{LiCl}, 130 \mathrm{mM} \mathrm{KCl}$, and sucrose $(65 \mathrm{mM}$ for CC cells and 55 $\mathrm{mM}$ for AA cells). This procedure yields cells with $7 \mathrm{mmol} \mathrm{Li} /$ liter of cells and $1.5 \mathrm{mmol} \mathrm{Na}$ /liter of cells, with near saturation of the internal sites with $\mathrm{Li}$ and little competitive inhibition by internal $\mathrm{Na}$. The $\mathrm{Li}$ efflux was measured into media containing either $140 \mathrm{mM}$ choline chloride or $140 \mathrm{mM} \mathrm{NaCl}$, in the presence of both ouabain and bumetanide. The incubation times were 5 and $65 \mathrm{~min}$, with triplicate samples. The hematocrit of the efflux cell suspension was $3 \%$. The $\mathrm{Na}-\mathrm{Li}$ countertransport was estimated as the difference between the $\mathrm{Li}$ efflux into $\mathrm{Na}$ and $\mathrm{Na}$-free media (8). $\mathrm{MgCl}_{2}$ was kept constant in all media and washing solutions at $1 \mathrm{mM}$. All media contained $10 \mathrm{mM}$ Tris-MOPS, $\mathrm{pH} 7.4$, at $37^{\circ} \mathrm{C}$, and $10 \mathrm{mM}$ glucose. 
Concentrations of the inhibitors were $0.1 \mathrm{mM}$ for ouabain, $0.01 \mathrm{mM}$ for bumetanide, and $1 \mathrm{mM}$ for furosemide.

CC cells suspended in a medium with the osmolarity of plasma are shrunken compared to AA cells. As a result, 1 liter of CC cells contains more cells and more total membrane area than 1 liter of AA cells. To enable comparison of fluxes per unit of membrane area (independent of cell volume), we calculated the surface area of CC and AA erythrocytes, using Murphy's data (2) and Ponder's equation. An important assumption in this calculation is that all water is osmotically active in both CC and AA erythrocytes, as we previously demonstrated (4). This results in a lytic volume of $165 \mu \mathrm{m}^{3}$ and a cell membrane area of $145 \mu \mathrm{m}^{2}$, in both CC and AA cells. From the mean corpuscular volume data, 1 liter of cells contains $1.11 \times 10^{13}$ cells in $\mathrm{AA}$ cells and $1.43 \times 10^{13}$ cells in CC cells. Therefore, the total membrane area is $1.6 \times 10^{7} \mathrm{~cm}^{2}$ in 1 liter of AA cells and $2.07 \times 10^{7}$ $\mathrm{cm}^{2}$ in CC. Making use of these estimates, the reader can convert the unit of the fluxes to unit of membrane area, as desired.

Chemicals. $\mathrm{KCl}, \mathrm{NaCl}$, and $\mathrm{MgCl}_{2}$ were purchased from Mallinckrodt, Inc., St. Louis, MO. Tris, albumin (bovine, fraction V), MOPS, EGTA, ouabain, trifluoperazine, chlorpromazine, acetazolamide, quinine, and 3,4,5-trimethoxybenzoic acid 8-(diethylamino)-octyl ester (TMB-8) were purchased from Sigma Chemical Co., St. Louis, MO. $N$-methyl D-glucamine was purchased from Aldrich Chemical Co., Inc., Milwaukee, WI. Choline chloride, A23187, and 4,4'-diisothiocyanostilbene-2,2'disulfonic acid (DIDS) were purchased from CalbiochemBehring Corp., La Jolla, CA. Radioisotopes $\left({ }^{22} \mathrm{Na}\right.$ and $\left.{ }^{86} \mathrm{Rb}\right)$ were purchased from New England Nuclear, Boston, MA. Furosemide was a gift of Hoechst-Russel Pharmaceuticals, Inc., Somerville, NJ. Nystatin was from E. R. Squibb \& Sons, Inc., Princeton, NJ. Bumetanide was a gift from Laboratoire Leo, Vernouillet, France. 3,3'-diethylthiadicarbocyanine iodide was from Koch-Light Laboratories Ltd., Colnbrook Books, England. Amiloride was a gift of Merck Sharp \& Dohme, Rahway, NJ.

All solutions were prepared using double-distilled water.

\section{Results}

\section{Electrolyte composition and water content}

CC cells contain fewer cations and less water than AA cells, as shown in Table I. Despite a measured reduction of $40 \mathrm{meq} /$ $\mathrm{kg}$ of dry cell solids in the concentration of impermeant negative anions, $\mathrm{CC}$ cells have normal $\mathrm{Cl}^{-}$(and $\mathrm{OH}^{-}$) ratio (4). This occurs because of the reduction in cation content. The reduction of cation content is due mainly to a reduction of $\mathrm{K}$ content ( $-45 \mathrm{mmol} / \mathrm{kg}$ of dry cell solids); the $\mathrm{Na}$ content is also somewhat reduced $(-10 \mathrm{mmol} / \mathrm{kg}$ of dry cell solids). CC cells have also an increased 2,3-DPG concentration ( 9 vs. $6.8 \mathrm{mmol} / \mathrm{liter}$ of cell water). MCHC was $37 \mathrm{~g} / \mathrm{dl}$ in CC cells and $33 \mathrm{~g} / \mathrm{dl}$ in AA cells, whereas the reticulocyte count was $2.8 \%$ in $\mathrm{CC}$ as compared with $1 \%$ in AA cells.

\section{Regulation of cell $K$ content and volume}

The $\mathrm{K}$ and water content of $\mathrm{CC}$ cells was increased by the nystatin procedure (without changing cell $\mathrm{Na}$ ). The cells were then incubated in a solution containing $140 \mathrm{mM} \mathrm{NaCl}, 4 \mathrm{mM}$ $\mathrm{KCl}, 1 \mathrm{mM}$ phosphate, $10 \mathrm{mM}$ Tris-MOPS, pH 7.4, at $37^{\circ} \mathrm{C}$, and $10 \mathrm{mM}$ glucose. As shown in Fig. 1, swollen CC cells (initial water content, wt/wt, 66.8\%) shrunk back toward their original volume within an 8-h period (final water content, wt/ wt, $61 \%$ ). This process was not inhibited by ouabain or bumetanide. As shown in Table II, this process took place through a reduction of the total cation content (from 272 to $200 \mathrm{mmol} / \mathrm{kg}$ of dry cell solids), mainly due to a loss of $\mathrm{K}$

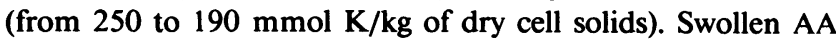

Table I. Electrolyte Composition of CC and AA Erythrocytes

\begin{tabular}{|c|c|c|}
\hline & $\mathrm{CC}$ & AA \\
\hline \multicolumn{3}{|l|}{ Water content } \\
\hline (\% weight/weight) & $59.5 \pm 0.5$ & $62.7 \pm 0.8$ \\
\hline (\% weight/volume) & 65.5 & 69 \\
\hline ( $\mathrm{kg} / \mathrm{kg}$ of dry cell solids) & 1.47 & 1.68 \\
\hline Cation content & \multicolumn{2}{|c|}{ mmol/liter of cells } \\
\hline $\mathrm{Na}$ & $5.1 \pm 0.5$ & $9.4 \pm 1.4$ \\
\hline $\mathbf{K}$ & $89.7 \pm 2.8$ & $97.9 \pm 2.2$ \\
\hline \multirow[t]{2}{*}{ Total } & $94.8 \pm 2.7$ & $107.2 \pm 2.4$ \\
\hline & \multicolumn{2}{|c|}{$\mathrm{mmol} / \mathrm{liter}$ of cell water } \\
\hline $\mathrm{Na}$ & 8 & 14 \\
\hline $\mathbf{K}$ & 137 & 142 \\
\hline \multirow[t]{2}{*}{ Total } & 145 & 156 \\
\hline & \multicolumn{2}{|c|}{$\mathrm{mmol} / \mathrm{kg}$ of dry cell solids } \\
\hline $\mathrm{Na}$ & 11 & 23 \\
\hline $\mathbf{K}$ & 201 & 238 \\
\hline Total & 212 & 261 \\
\hline \multicolumn{3}{|l|}{ Chloride ratio } \\
\hline$\left(\mathrm{Cl}_{\mathrm{i}} / \mathrm{Cl}_{\mathrm{o}}\right)$ & $0.71 \pm 0.05$ & $0.70 \pm 0.025$ \\
\hline \multicolumn{3}{|l|}{ 2,3-DPG } \\
\hline (mmol/liter of cell water) & $9.0 \pm 0.3$ & $6.8 \pm 0.35$ \\
\hline
\end{tabular}

The data are the mean \pm standard deviation of at least three measurements in each of the two CC patients and of five normal controls (AA).

cells showed no evidence of volume regulation, during the 8$h$ incubation (Fig. 1; Table II). The reduction of water and cation content of swollen CC cells was inhibited when the external medium contained $140 \mathrm{mM} \mathrm{KCl}$.

When AA or CC cells are incubated in hypotonic medium

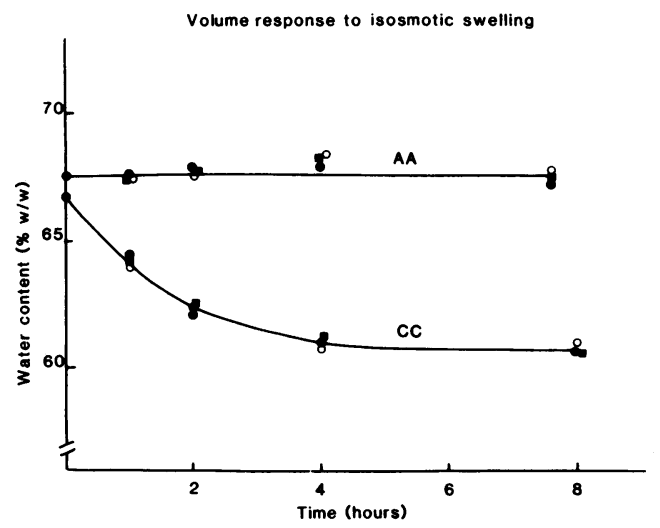

Figure 1. Cell water content (\% weight/weight) as a function of time in CC and AA cells. The cation and water content were increased by the nystatin-loading procedure. The nystatin-loading solution contained $10 \mathrm{mM} \mathrm{NaCl}, 130 \mathrm{mM} \mathrm{KCl}$, and $20 \mathrm{mM}$ sucrose. The cells were then incubated in a medium containing $140 \mathrm{mM} \mathrm{NaCl}, 4 \mathrm{mM}$ $\mathrm{KCl}, 1 \mathrm{mM}$ phosphate, $10 \mathrm{mM}$ glucose, and $10 \mathrm{mM}$ Tris-MOPS, $\mathrm{pH}$ 7.4 at $37^{\circ} \mathrm{C}$, without $(\bullet)$ and with $0.1 \mathrm{mM}$ ouabain $(\bullet)$ and with 0.1 $\mathrm{mM}$ ouabain and $0.01 \mathrm{mM}$ bumetanide (o). Dry weight was measured in duplicate at each time interval. The values for $\mathrm{CC}$ cells are from two different experiments in the same subject. 
Table II. Regulation of Cation and Water Content in $C C$ and $A A$ Erythrocytes

\begin{tabular}{|c|c|c|c|c|c|}
\hline \multirow[b]{3}{*}{ Time (h) + inhibitor } & \multicolumn{5}{|c|}{ Content } \\
\hline & \multirow[b]{2}{*}{ Water } & & \multicolumn{3}{|c|}{ Cation } \\
\hline & & & $\mathrm{Na}$ & $\mathbf{K}$ & $\mathrm{Na}+\mathrm{K}$ \\
\hline & $w t / w t$ & $\begin{array}{l}\mathrm{kg} / \mathrm{kg} \text { of dry } \\
\text { cell solids }\end{array}$ & \multicolumn{3}{|c|}{$\mathrm{mmol} / \mathrm{kg}$ of dry cell solids } \\
\hline \multicolumn{6}{|l|}{$\mathrm{CC}$} \\
\hline 0 & 66.8 & 2.01 & 22 & 250 & 272 \\
\hline 8 & 61.0 & 1.56 & 12 & 190 & 202 \\
\hline $8+$ ouabain & 60.8 & 1.55 & 39 & 158 & 197 \\
\hline $\begin{array}{l}8+\text { ouabain } \\
+ \text { bumetanide }\end{array}$ & \multicolumn{4}{|c|}{$8+$ ouabain } & 197 \\
\hline \multicolumn{6}{|l|}{ AA } \\
\hline 0 & 67.4 & 2.07 & 30 & 287 & 317 \\
\hline 8 & 67.2 & 2.05 & 19 & 286 & 305 \\
\hline $8+$ ouabain & 67.5 & 2.07 & 50 & 259 & 309 \\
\hline \multicolumn{6}{|l|}{$8+$ ouabain } \\
\hline + bumetanide & 67.7 & 2.09 & 51 & 260 & 311 \\
\hline
\end{tabular}

The cells were swollen by increasing cation content isosmotically. Data from the experiments reported in Fig. 1.

$(100 \mathrm{mM} \mathrm{NaCl})$, in the presence of both ouabain and bumetanide, they instantly swell. The water gain is different between $\mathrm{CC}$ and AA cells (wt/wt indices change from 60 to $65.5 \%$ for $\mathrm{CC}$ and from 62.5 to $69 \%$ for $\mathrm{AA}$ ). This difference in water gain reflects the differences in the cation content of the fresh CC and AA cells. Again, unlike AA cells, CC cells shrunk back toward their original volume over a 4-h time period (Fig. 2). Thus, $C C$ cells can regulate their volume even when incubated in hypotonic medium, in the presence of ouabain and bumetanide.

Properties of the ouabain- and bumetanide-resistant $K$ and $N a$ transport in $C C$ and $A A$ cells

The ouabain and bumetanide (henceforth abbreviated OB) -resistant $\mathrm{Na}$ and $\mathrm{K}$ fluxes (leak pathways) were studied in $\mathrm{CC}$

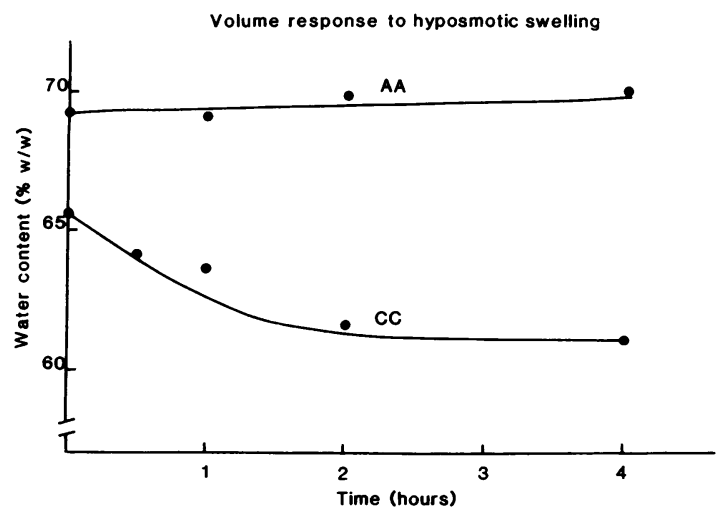

Figure 2. Cell water content (\% weight/weight) as a function of time in CC and AA cells. The cells were incubated in a medium containing $100 \mathrm{mM} \mathrm{NaCl}, 1 \mathrm{mM} \mathrm{MgCl} 2,10 \mathrm{mM}$ Tris-MOPS, pH 7.4 at $37^{\circ} \mathrm{C}, 10 \mathrm{mM}$ glucose, $0.1 \mathrm{mM}$ ouabain, and $0.01 \mathrm{mM}$ bumetanide (osmolarity $=220$ mosM). Dry weight was measured in duplicate at each time interval. The results shown here are from one experiment in a normal subject and three experiments in two $\mathrm{CC}$ patients. and AA cells. Table III shows measurements of unidirectional ${ }^{22} \mathrm{Na}$ and ${ }^{86} \mathrm{Rb}$ fluxes for $\mathrm{CC}$ and $\mathrm{AA}$ cells in a medium containing $140 \mathrm{mM} \mathrm{NaCl}$ and $4 \mathrm{mM} \mathrm{KCl}$. The intracellular $\mathrm{Na}$ content was $4 \mathrm{mmol} / \mathrm{liter}$ of cells in both $\mathrm{CC}$ and AA cells (nystatin procedure). It can be seen, that CC cells had a 25fold greater rate constant for $\mathrm{K}$ influx and a sixfold greater rate constant for $\mathrm{K}$ efflux than was observed in AA cells. The rate constants for $\mathrm{Na}$ efflux and influx were greater in $\mathrm{CC}$ than in AA cells by a factor of 3 .

\section{Volume dependence}

Dependence of $O B$-resistant $K$ efflux on external osmolarity. The osmolarity of the medium was changed by adding varying amounts of choline chloride to $100 \mathrm{mM} \mathrm{NaCl}$. In hypotonic medium, $(100 \mathrm{mM} \mathrm{NaCl}, 220 \mathrm{mosM})$ the cell water content of CC cells increases to 65.5 (wt/wt), the concentration of negative hemoglobin charges is therefore reduced, $\mathrm{Cl}^{-}$moves into the cell, and the $\mathrm{Cl}^{-}$ratio increases $(0.76$ at 220 mosM compared to 0.71 at 300 mosM). The increase in the $\mathrm{Cl}^{-}$ratio, at constant external $\mathrm{pH}$, is accompanied by an increase in the internal $\mathrm{pH}(+0.025 \mathrm{pH} \mathrm{U})$ and also makes the membrane potential more positive by $2.5 \mathrm{mV}$. All of these variables change in the opposite direction when choline chloride is added and the osmolarity of the medium is increased above normal values. As shown in Fig. 3, the dependence of OBresistant $\mathrm{K}$ efflux on osmolarity is different in $\mathrm{CC}$ and $\mathrm{AA}$ cells. In hypotonic medium, the $\mathrm{K}$ efflux is greatly increased in CC but not in AA cells. At normal osmolarity (300 mosM), OB-resistant $\mathrm{K}$ efflux is about five times higher in $\mathrm{CC}$ than in control AA cells. It is worth noting that $\mathrm{K}$ permeability is the same in CC and AA cells, when the osmolarity of the medium is above 350 mosM.

Dependence of OB-resistant $K$ efflux on cell volume. To distinguish between the roles of osmolarity and cell volume in regulating the $\mathrm{K}$ leak, we measured the OB-resistant $\mathrm{K}$ efflux in cells with different volumes at constant external $\mathrm{pH}$ and osmolarity. Cell volume was varied by varying the cell cation content using the nystatin procedure. The internal $\mathrm{Na}$ concentration was kept at 4-5 mmol/liter of cells. As shown in Fig. 4 , the $\mathrm{K}$ leak is dependent on cell volume (or the concentration of hemoglobin and/or other nonpermeant intracellular solutes) in both normal and CC cells. The stimulation of OB-resistant $\mathrm{K}$ efflux produced by cell swelling is significantly greater in $\mathrm{CC}$ cells. An increase in outward $\mathrm{K}$ leak was also described in swollen AA human red cells by Adragna and Tosteson (9).

\section{pH dependence}

Dependence of $O B$-resistant $K$ efflux and influx on both external and internal $\mathrm{pH}$. The OB-resistant $\mathrm{K}$ efflux was measured from $\mathrm{CC}$ and AA cells into media with a constant osmolarity and chloride concentrations, but with the $\mathrm{pH}$ varying from 6.25 to 8.0. Under these conditions, when the external pH is reduced, internal $\mathrm{pH}$ also falls, and the negative charges on hemoglobin are titrated, $\mathrm{Cl}^{-}$enters to preserve electroneutrality, and the $\mathrm{Cl}^{-}$ratio increases. The increase in internal $\mathrm{Cl}^{-}$ content increases water content and cell volume and also results in a more positive membrane potential (10). On the other hand, when the external $\mathrm{pH}$ is increased, internal $\mathrm{pH}$ rises, hemoglobin is titrated to become more negatively charged and $\mathrm{Cl}^{-}$moves out to preserve electroneutrality. As a consequence, the chloride distribution ratio and cell volume are decreased, and the membrane potential becomes more negative. 


\begin{tabular}{lllllll}
\hline & & & & \multicolumn{2}{c}{ Rate constant } & \\
\cline { 5 - 6 } & CC & AA & CC/AA ratio & CC & AA & CC/AA ratio \\
\hline & mmol/liter of cells $\times h$ & mmol/liter of cells $\times h$ & & $h^{-1}$ & $h^{-1}$ & \\
Na efflux & $0.720 \pm 0.12$ & $0.200 \pm 0.01$ & 3.6 & 0.155 & 0.047 & 3.3 \\
Na influx & $1.875 \pm 0.09$ & $0.670 \pm 0.01$ & 2.8 & 0.013 & 0.005 & 2.6 \\
K efflux & $6.060 \pm 0.24$ & $1.175 \pm 0.07$ & 5.9 & 0.077 & 0.013 & 5.9 \\
K influx & $0.900 \pm 0.05$ & $0.035 \pm 0.01$ & 25.7 & 0.225 & 0.009 & 25.0 \\
\end{tabular}

The unidirectional ${ }^{22} \mathrm{Na}$ and ${ }^{86} \mathrm{Rb}$ fluxes were measured in $\mathrm{CC}$ and $\mathrm{AA}$ cells containing $4 \mathrm{mmol} \mathrm{Na/liter}$ of cells and $92 \mathrm{mmol} \mathrm{K} /$ liter of cells (nystatin-loading procedure). The external medium contained $140 \mathrm{mM} \mathrm{NaCl}, 4 \mathrm{mM} \mathrm{KCl}, 1 \mathrm{mM} \mathrm{MgCl}, 10 \mathrm{Tris}-\mathrm{MOPS}, \mathrm{pH} 7.4$ at $37^{\circ} \mathrm{C}, 10$ $\mathrm{mM}$ glucose, $0.1 \mathrm{mM}$ ouabain, and $0.01 \mathrm{mM}$ bumetanide. The data are the mean \pm standard deviation of two experiments in the same CC patient and in two AA controls.

As shown in Fig. 5, the $\mathrm{pH}_{\mathrm{o}}$ dependence of OB-resistant $\mathrm{K}$ efflux differed in $\mathrm{CC}$ and $\mathrm{AA}$ cells. The OB-resistant $\mathrm{K}$ efflux from $\mathrm{CC}$ cells had a bell-shaped dependence on external $\mathrm{pH}$, with maximal activation $(20-30 \mathrm{mmol} / \mathrm{liter}$ of cells $\times \mathrm{h})$ at pH 6.8-7.0. At external pH 7.4, the $\mathrm{K}$ leak was about five times higher in $\mathrm{CC}$ than in normal cells. The $\mathrm{K}$ leaks in $\mathrm{CC}$ and $\mathrm{AA}$ cells were equal when the external $\mathrm{pH}$ was higher than 7.5.

The unidirectional $\mathrm{K}$ influx $\left({ }^{86} \mathrm{Rb}\right.$ tracer $)$ was measured in a medium containing $140 \mathrm{mM} \mathrm{NaCl}, 5 \mathrm{mM} \mathrm{KCl}$, and $\mathrm{OB}$. It showed a $\mathrm{pH}_{\mathrm{o}}$ dependence similar to that of the $\mathrm{K}$ efflux, with maximal stimulation at $\mathrm{pH}_{\mathrm{o}} 7.0$, and inhibition at alkaline pH. In hypotonic medium $(100 \mathrm{mM} \mathrm{NaCl})$ at $\mathrm{pH}_{\mathrm{o}} 7.4, \mathrm{~K}$ influx was stimulated, whereas hypertonic media inhibited $\mathrm{K}$ influx. Therefore, the dependence of $\mathrm{K}$ influx on $\mathrm{pH}$ and volume was similar to that found for the $K$ efflux.

The interpretation of these results is made difficult by the simultaneous variations of internal $\mathrm{pH}, \mathrm{Cl}^{-}$ratio, and membrane potential, when the external $\mathrm{pH}$ is changed. In order to determine the relative importance of these parameters, we

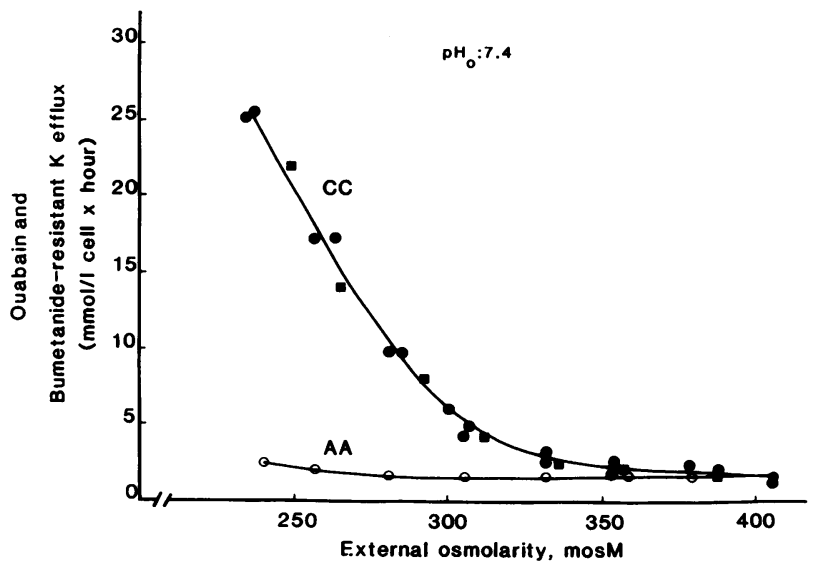

Figure 3. OB-resistant $\mathrm{K}$ efflux as a function of osmolarity in $\mathrm{CC}$ and AA cells. The medium contained $100 \mathrm{mM} \mathrm{NaCl}(\boldsymbol{m})$ or $100 \mathrm{mM}$ choline chloride (๑), $1 \mathrm{mM} \mathrm{MgCl}_{2}, 10 \mathrm{mM}$ Tris-MOPS, pH 7.4 at $37^{\circ} \mathrm{C}, 10 \mathrm{mM}$ glucose, $0.1 \mathrm{mM}$ ouabain, and $0.01 \mathrm{mM}$ bumetanide. The osmolarity was increased by adding choline chloride $(0-100$ $\mathrm{mM})$. The values for AA cells are the mean of two experiments in two subjects. The values for $\mathrm{CC}$ cells are from two different experiments in the same patient. Similar results were obtained in a second CC patient. studied the effect of external $\mathrm{pH}$ at constant internal $\mathrm{pH}, \mathrm{Cl}$ concentration, and membrane potential.

Dependence of $O B$-resistant $K$ efflux on external versus internal $\mathrm{pH}$. The dependence of $\mathrm{K}$ transport on $\mathrm{pH}_{\mathrm{o}}$ was studied in cells treated with DIDS $(150 \mu \mathrm{M})$ and acetazolamide (1 mM). Under these conditions, facilitated $\mathrm{Cl}^{-}$and $\mathrm{HCO}_{3}^{-}$ exchange and carbonic anhydrase are inhibited, the rates of equilibration of chloride and protons are very low, and therefore the external $\mathrm{pH}$ can be changed whereas internal $\mathrm{pH}$, chloride concentration and membrane potential remain relatively constant (11). As can be seen in Fig. 6, at any given external pH, $\mathrm{K}$ efflux was inhibited when the internal $\mathrm{pH}$ became alkaline. At any given internal $\mathrm{pH}$, there was no difference in the $\mathrm{K}$ efflux with external pH 6.7 or 7.4. However, external pH 8.0 partially inhibited $\mathrm{K}$ efflux in cells with acid internal $\mathrm{pH}$. This effect could be related to some proton equilibration due to the high proton concentration gradient present in the experiment.

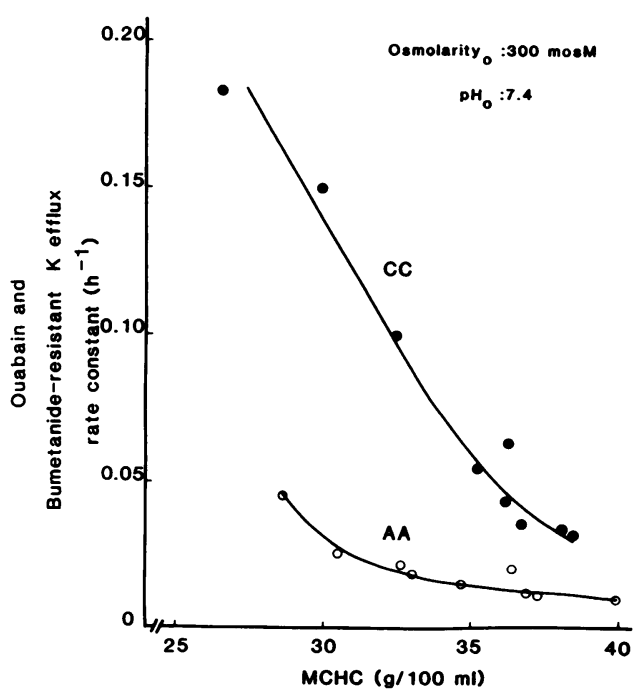

Figure 4. OB-resistant $\mathrm{K}$ efflux as a function of cell volume (MCHC) in CC and AA cells. The water content was varied with the nystatinloading procedure, incubating $\mathrm{CC}$ and $\mathrm{AA}$ cells in a solution containing $10 \mathrm{mM} \mathrm{NaCl}, 130 \mathrm{mM} \mathrm{KCl}$, and $20-100 \mathrm{mM}$ sucrose. $\mathrm{K}$ efflux was measured in a medium containing $140 \mathrm{mM} \mathrm{NaCl}, 1 \mathrm{mM} \mathrm{MgCl}$, $10 \mathrm{mM}$ Tris-MOPS, pH 7.4 at $37^{\circ} \mathrm{C}, 10 \mathrm{mM}$ glucose, $0.1 \mathrm{mM}$ ouabain, and $0.01 \mathrm{mM}$ bumetanide. The data are from one of two experiments in the same CC patient. 


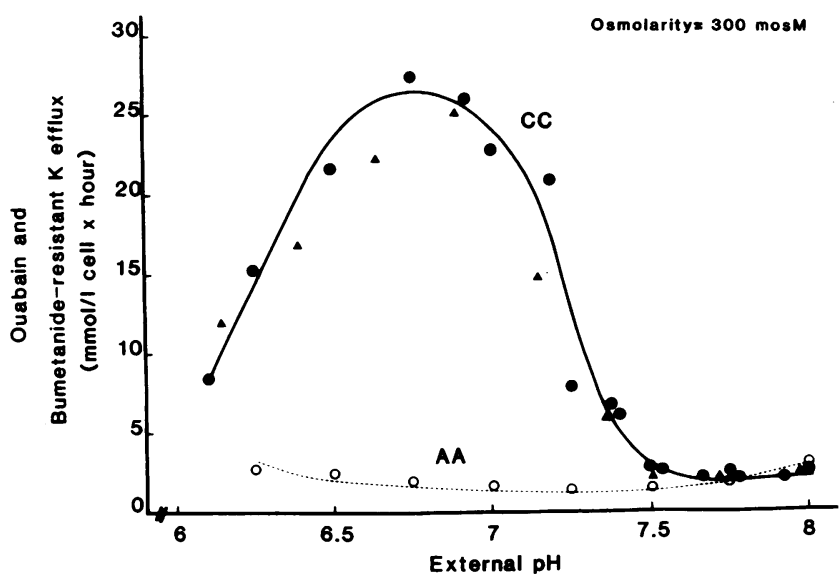

Figure 5. OB-resistant $\mathrm{K}$ efflux as a function of external $\mathrm{pH}$ in $\mathrm{CC}$ and AA cells. The cells were incubated in a medium containing 140 $\mathrm{mM} \mathrm{NaCl}(\Delta)$ or $140 \mathrm{mM}$ choline chloride (๑), $1 \mathrm{mM} \mathrm{MgCl}, 10$ $\mathrm{mM}$ Tris-MOPS, $\mathrm{pH} 6.2-8.0$ at $37^{\circ} \mathrm{C}, 10 \mathrm{mM}$ glucose, $0.1 \mathrm{mM}$ ouabain, and $0.01 \mathrm{mM}$ bumetanide. The values for $\mathrm{AA}$ are the mean of two experiments in two subjects. The values for $\mathrm{CC}$ are from two different experiments in the same patient. Similar results were obtained in a second CC patient.

We conclude that OB-resistant $\mathrm{K}$ efflux is not dependent on external $\mathrm{pH}$ or on the $\mathrm{pH}$ gradient across the membrane. This result makes it unlikely that the $K$ transport pathway involves a $\mathrm{K} / \mathrm{H}$ exchange. However, the simultaneous changes in internal $\mathrm{pH}$, internal chloride concentration, membrane potential, and cell volume do not allow a clear separation between the effect of these factors on OB-resistant $\mathrm{K}$ transport. Clearly, further experiments are necessary to resolve this issue.

Dependence of $O B$-resistant $K$ efflux on external $p H$ at different osmolarities. To study the relative importance of external (and internal) $\mathrm{pH}$ and cell volume, the $\mathrm{pH}_{\mathrm{o}}$ dependence

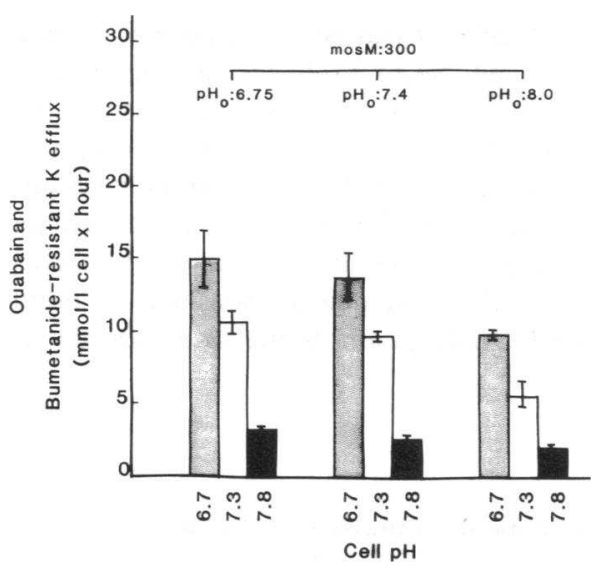

Figure 6. OB-resistant $\mathrm{K}$ efflux at three different external $\mathrm{pH}$ values from $\mathrm{CC}$ cells having three different internal $\mathrm{pH}$ values. $\mathrm{CC}$ cells were incubated in a medium similar to that described in Fig. 5, pH 6.75, 7.4, and 8.0, with addition of DIDS $(150 \mu \mathrm{M})$ and acetazolamide $(1 \mathrm{mM})$. The internal $\mathrm{pH}$ was calculated from the external $\mathrm{pH}$ and the $\mathrm{Cl}$ distribution ratio. $\mathrm{K}$ efflux was measured from each of the three sets of cells in media with three different $\mathrm{pH}$ values $(6.75,7.4$, and 8.0). The results are the mean \pm standard deviation of two experiments in the same $\mathrm{CC}$ subject.

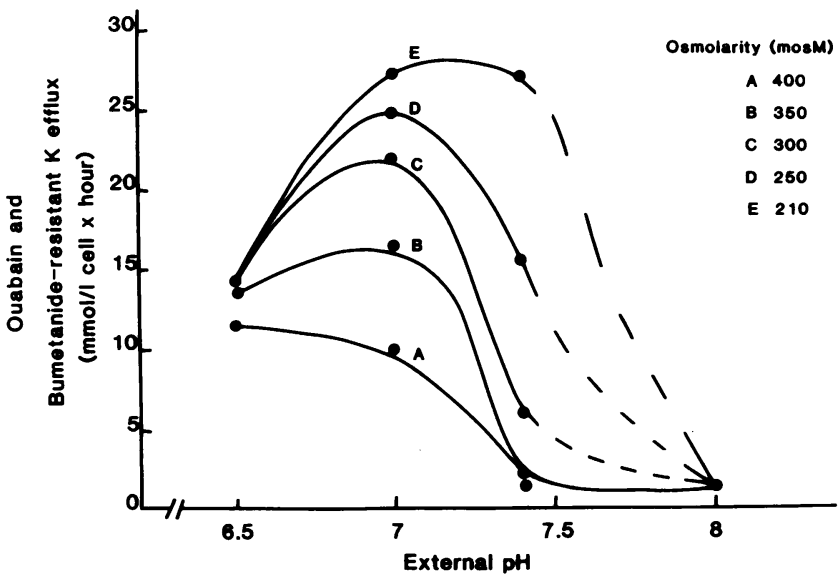

Figure 7. OB-resistant $\mathrm{K}$ efflux as a function of external $\mathrm{pH}$, at different osmolarities in CC cells. The medium contained $100 \mathrm{mM}$ $\mathrm{NaCl}, 1 \mathrm{mM} \mathrm{MgCl}, 10 \mathrm{mM}$ Tris-MOPS, pH 6.5-8.0, at $37^{\circ} \mathrm{C}, 10$ $\mathrm{mM}$ glucose, $0.1 \mathrm{mM}$ ouabain, and $0.01 \mathrm{mM}$ bumetanide. The osmolarity was increased by adding choline chloride $(0-100 \mathrm{mM})$.

The data are from one of two experiments in the same $\mathrm{CC}$ patient.

of OB-resistant $\mathrm{K}$ efflux was measured at different osmolarities. As can be seen in Fig. 7, alkaline (8.0) and acid (6.5) pH, inhibited OB-resistant $\mathrm{K}$ efflux in hypotonic, isotonic, and hypertonic media. In contrast, when $\mathrm{K}$ efflux was activated by $\mathrm{pH}_{\mathrm{o}}$ 7.0, cell swelling further increased and cell shrinkage inhibited the OB-resistant $\mathrm{K}$ efflux in $\mathrm{CC}$ cells.

\section{Effect of different inhibitors on the OB-resistant $K$ efflux} and its relationship with the $C a$-activated $K$ permeability

In order to understand better the properties of the OB-resistant $\mathrm{K}$ leak in CC cells, the effect of different inhibitors was tested. When the inhibitor of $\mathrm{Na}$ transport amiloride (12) (1 mM) was added to the incubation medium, it inhibited $20 \%$ of the $\mathrm{K}$ efflux, under both basal conditions, and when the $\mathrm{K}$ efflux was stimulated by $\mathrm{pH} 7.0$ or hypotonicity. It is possible that this effect is related to an alkaline shift in internal pH produced by the entry of the weak base amiloride (12), rather than a specific effect of the drug.

To investigate the role of $\mathrm{Ca}$ in the $\mathrm{K}$ permeability of $\mathrm{CC}$ cells, the concentration of internal free $\mathrm{Ca}$ was reduced by adding the ionophore A23187 $(40 \mu \mathrm{mol} / \mathrm{liter}$ of red cells; hematocrit $=1 \%)$ and EGTA $(0.1-1.0 \mathrm{mM})(13)$. This treatment did not significantly affect the $\mathrm{K}$ efflux from $\mathrm{CC}$ cells, even when it was stimulated by hypotonicity or $\mathrm{pH}_{\mathrm{o}} 7.0$ (Table IV). The effect of various inhibitors of the Ca-activated $\mathrm{K}$ channel was also tested (5). As can be seen in Table V, none of the inhibitors of the Gardos pathway that we tested significantly reduced the volume- or $\mathrm{pH}$-dependent $\mathrm{K}$ efflux from $\mathrm{CC}$ cells. We conclude that the increased $\mathrm{K}$ leak in $\mathrm{CC}$ cells is not a Ca-dependent process.

Because divalent cations inhibit $\mathrm{Na}$ and $\mathrm{K}$ fluxes in normal human red cells (14), we also tested the effect of external $\mathrm{Mg}$. At low concentrations (0-8 $\mathrm{mM}$ ) of external $\mathrm{Mg}$, only a slight inhibition of the OB-resistant $\mathrm{K}$ efflux was found in $\mathrm{CC}$ cells, compared to the $50 \%$ inhibition found in AA cells. High $\mathbf{M g}$ concentrations (16-20 mM) slightly stimulated $\mathrm{K}$ efflux from $\mathrm{CC}$ cells, but inhibited $\mathrm{K}$ efflux from AA cells. Therefore, another distinguishing characteristic of the OB-resistant $\mathrm{K}$ 
Table IV. Effect of Internal Ca Removal on OB-resistant $K$ Efflux from CC Cells

\begin{tabular}{|c|c|c|c|}
\hline \multirow[b]{2}{*}{$\mathrm{pH}_{\mathrm{o}}$} & \multirow[b]{2}{*}{ Osmolarity } & \multicolumn{2}{|c|}{ Ouabain and bumetanide-resistant $K$ efflux } \\
\hline & & EGTA & A23187 and EGTA \\
\hline & $\operatorname{mos} M$ & \multicolumn{2}{|c|}{ mmol/liter of cells $\times h$} \\
\hline 7.4 & 300 & $8.6 \pm 1.5$ & $7.4 \pm 0.9$ \\
\hline 6.75 & 300 & $26.9 \pm 2.4$ & $24.4 \pm 1.7$ \\
\hline 7.4 & 210 & $36.0 \pm 2.6$ & $35.1 \pm 2.1$ \\
\hline
\end{tabular}

The efflux was measured in media containing 100 or $142 \mathrm{mM}$ choline chloride, $0.15 \mathrm{mM} \mathrm{MgCl}_{2}, 10 \mathrm{mM}$ Tris-MOPS, $10 \mathrm{mM}$ glucose, $0.1 \mathrm{mM}$ ouabain, and $0.01 \mathrm{mM}$ bumetanide. The A 23187 concentration was $40 \mu \mathrm{mol} / \mathrm{liter}$ of cells for a hematocrit of the flux medium of $1 \%$. The EGTA concentration was $0.1-1.0 \mathrm{mM}$. The results are the mean \pm standard deviation of three different experiments in the same CC patient.

efflux in CC cells seems to be the lack of inhibition by divalent cations.

\section{Effect of external $\mathrm{Na}$ and external $\mathrm{K}$ on the OB-resistant $K$ efflux}

To demonstrate that the increased $\mathrm{K}$ leak in $\mathrm{CC}$ cells does not take place through a $\mathrm{K}_{\mathrm{i}} / \mathrm{Na}_{\mathrm{o}}$ exchange mechanism, the $\mathrm{OB}$ resistant $\mathrm{K}$ efflux was measured in $\mathrm{Na}$ media and in $\mathrm{Na}$-free media (choline substitution), at constant external $\mathrm{MgCl}_{2}$ (1 $\mathrm{mM}$ ), as a function of $\mathrm{pH}_{\mathrm{o}}$ and osmolarity. As can be seen in Figs. 3 and 5, there was no effect of removing external $\mathrm{Na}$. $\mathrm{K}$ efflux has the same magnitude and the same $\mathrm{pH}$ and volume dependence in $\mathrm{Na}$-free medium as in $\mathrm{Na}$ medium. Therefore, the increased $\mathrm{K}$ permeability of $\mathrm{CC}$ cells does not take place through a $\mathrm{K}_{\mathrm{i}} / \mathrm{Na}_{\mathrm{o}}$ exchange mechanism.

To determine the effect of external $\mathrm{K}$ on the OB-resistant $\mathrm{K}$ efflux from $\mathrm{CC}$ cells, $\mathrm{K}$ efflux was measured into choline media, varying external $\mathrm{K}$ from 0 to $140 \mathrm{mM}$, at constant $\mathrm{pH}_{\mathrm{o}}$ (7.4) and osmolarity (300 mosM). Because external $\mathrm{K}$ did not stimulate $\mathrm{K}$ efflux from $\mathrm{CC}$ cells, it is reasonable to infer

Table V. Effect of Inhibitors of the Ca-activated $\mathrm{K}$ Permeability on the OB-resistant $K$ Efflux from CC Cells

\begin{tabular}{llc}
\hline & \multicolumn{2}{l}{ OB-resistant K efflux } \\
\cline { 2 - 3 } $\mathrm{pH}_{\mathrm{o}}$ & 7.0 & 7.40 \\
Osmolarity $(\operatorname{mos} M)$ & 300 & 220 \\
\hline & \multicolumn{2}{l}{ mmol/liter of cells $\times h$} \\
Control & $28.1 \pm 3.3$ & $30.6 \pm 5.1$ \\
Quinine $(75 \mu \mathrm{M})$ & $29.5 \pm 3.2$ & $33.6 \pm 5.1$ \\
Carbocyanine $(10 \mu \mathrm{M})$ & $31.2 \pm 1.6$ & $33.0 \pm 3.9$ \\
Trifluoperazine $(10 \mu \mathrm{M})$ & $33.5 \pm 2.6$ & $37.1 \pm 4.1$ \\
Chlorpromazine $(10 \mu \mathrm{M})$ & $34.6 \pm 1.9$ & $37.5 \pm 3.3$ \\
TMB-8 $(20 \mu \mathrm{M})$ & $27.4 \pm 1.9$ & $33.2 \pm 6.6$ \\
\hline
\end{tabular}

The medium contained $100 \mathrm{mM} \mathrm{NaCl}$, with or without $50 \mathrm{mM}$ choline chloride, $10 \mathrm{mM}$ Tris-MOPS, $1 \mathrm{mM} \mathrm{MgCl}, 10 \mathrm{mM}$ glucose, 0.1 $\mathrm{mM}$ ouabain, and $0.01 \mathrm{mM}$ bumetanide. The results are the mean \pm standard deviation of two experiments in the same CC patient. The hematocrit of the flux media was $1 \%$. TMB-8, trimethoxybenzoic acid 8(diethylamino)-octyl ester. that $\mathrm{K}$ efflux does not take place through a $\mathrm{K}_{\mathrm{i}} / \mathrm{K}_{\mathrm{o}}$ exchange mechanism. On the other hand, OB-resistant $K$ influx was stimulated by external $\mathrm{K}$. Although more work is needed on the effect of external $\mathrm{K}$ on the $\mathrm{K}$ efflux and influx pathways at different cell volumes, these properties suggest that the $O B$ resistant $\mathrm{K}$ movement in $\mathrm{CC}$ cells is driven primarily by the electrochemical gradient for $\mathrm{K}$.

\section{$O B$-resistant $N a$ influx and efflux in $C C$ and $A A$ cells:} effect of $\mathrm{pH}_{\mathrm{o}}$ and osmolarity

The OB-resistant ${ }^{22} \mathrm{Na}$ influx was measured as a function of $\mathrm{pH}_{\mathrm{o}}$, at constant osmolarity $(140 \mathrm{mM} \mathrm{NaCl})$, and as a function of osmolarity ( $100 \mathrm{mM} \mathrm{NaCl}+$ choline) at constant $\mathrm{pH}_{\mathrm{o}}$ (7.4). Under these conditions, we found that $\mathrm{Na}$ influx is independent of both $\mathrm{pH}$ and osmolarity (Table VI). In addition, there is no inhibition of this pathway by amiloride $(1 \mathrm{mM})$. In Table VI, measurements of OB-resistant $\mathrm{K}$ influx under similar conditions $(5 \mathrm{mM} \mathrm{KCl})$ are included. From a comparison of the two rate constants for $\mathrm{Na}$ and $\mathrm{K}$ influx, it can be seen that this pathway prefers $\mathrm{K}$ to $\mathrm{Na}$ by at least a factor of 10 .

To further characterize the cation selectivity of the volumeand $\mathrm{pH}$-dependent increase in $\mathrm{K}$ permeability in $\mathrm{CC}$ cells, they were made to contain $86 \mathrm{mmol} / \mathrm{liter}$ of cells $\mathrm{Na}$ and 7 $\mathrm{mmol} / \mathrm{liter}$ of cells $\mathrm{K}$ (nystatin procedure). The OB-resistant $\mathrm{Na}$ efflux was then measured in media containing choline chloride, as a function of $\mathrm{pH}_{\mathrm{o}}$ and osmolarity (Table VI). Under these conditions, the $\mathrm{Na}$ efflux was not dependent on osmolarity, but was stimulated by alkaline $\mathrm{pH}$. In the same table, we included measurement of $\mathrm{OB}$-resistant $\mathrm{K}$ efflux from fresh cells into choline medium. Again, from a comparison of the two rate constants for $\mathrm{Na}$ and $\mathrm{K}$ efflux, it can be concluded that the OB-resistant, volume- and $\mathrm{pH}$-dependent pathway for cation movement in $\mathrm{CC}$ cells prefers $\mathrm{K}$ to $\mathrm{Na}$ by at least a factor of 10 . More accurate definition of the cation selectivity of this pathway must await further experiments.

\section{Maximal rates of $\mathrm{Na}-\mathrm{K}$ pump, Na-K cotransport, and $N a-L i$ countertransport in CC and AA cells}

Table VII shows the maximal rates for the three transport systems in CC and AA cells. It can be seen that the maximal rates of $\mathrm{Na}-\mathrm{K}$ pump and $\mathrm{Na}-\mathrm{Li}$ exchange are significantly higher in CC than in AA cells. The bumetanide-sensitive Na$\mathrm{K}$ cotransport is lower in CC cells than in control cells. The differences in the maximal rates of the three transport systems remains significant even when the fluxes are calculated per number of cells or per unit of membrane area (see Methods). The affinity for internal $\mathrm{Na}$ of the ouabain-sensitive $\mathrm{Na}$ pump was measured in one $\mathrm{CC}$ subject and found to be normal (12 $\mathrm{mmol} /$ liter of cells).

\section{Discussion}

The erythrocytes of patients homozygous for hemoglobin C contain fewer impermeant negative charged groups than do erythrocytes from normal individuals homozygous for hemoglobin A (4). The cation content (and volume) of CC cells are also reduced to such an extent that the internal $\mathrm{Cl}^{-}$and $\mathrm{pH}$ are the same as in AA cells. This reduction in cation content is the result of differences in the cation transport systems in $\mathrm{CC}$ as compared with AA cells.

The reduction in cation content observed in CC cells in vivo can be duplicated in vitro. When the cation content of 
Table VI. OB-resistant Na and K Fluxes in CC Cells: Dependence on External pH and Osmolarity

\begin{tabular}{|c|c|c|c|c|c|c|}
\hline & \multicolumn{2}{|c|}{ External pH (300 mosM) } & \multicolumn{2}{|c|}{ Osmolarity (pH 7.4) } & & \\
\hline & \multirow{2}{*}{$\frac{7.0}{C C}$} & \multirow{2}{*}{$\begin{array}{l}8.0 \\
C C\end{array}$} & \multirow{2}{*}{$\frac{220 \operatorname{mos} M}{\mathrm{CC}}$} & \multirow{2}{*}{$\begin{array}{l}400 \text { mosM } \\
C C\end{array}$} & \multicolumn{2}{|c|}{ pH $7.4(300$ mosM $)$} \\
\hline & & & & & $\mathrm{CC}$ & AA \\
\hline \multicolumn{7}{|l|}{$A$} \\
\hline \multicolumn{7}{|l|}{$\mathrm{Na}$ influx (mmol) } \\
\hline $\begin{array}{r}\text { liter of cells } \times h) \\
\text { Rate constant }\left(h^{-1}\right)\end{array}$ & $\begin{array}{l}1.81 \pm 0.01 \\
0.013\end{array}$ & $\begin{array}{l}2.27 \pm 0.06 \\
0.016\end{array}$ & $\begin{array}{l}1.28 \pm 0.07 \\
0.013\end{array}$ & $\begin{array}{l}1.51 \pm 0.03 \\
0.015\end{array}$ & $\begin{array}{l}1.87 \pm 0.1 \\
0.013\end{array}$ & $\begin{array}{l}0.67 \pm 0.02 \\
0.005\end{array}$ \\
\hline \multicolumn{7}{|l|}{$\mathrm{K}$ influx (mmol) } \\
\hline Rate constant $\left(h^{-1}\right)$ & 0.358 & 0.018 & 0.516 & 0.020 & 0.21 & 0.009 \\
\hline \multicolumn{7}{|l|}{$\mathrm{K} / \mathrm{Na}$ influx } \\
\hline Rate constant ratio & 27 & 1.1 & 39.7 & 1.3 & 16.2 & 1.8 \\
\hline \multicolumn{7}{|l|}{$\boldsymbol{B}$} \\
\hline \multicolumn{7}{|l|}{$\mathrm{Na}$ efflux (mmol) } \\
\hline liter of cells $\times h$ ) & $8.70 \pm 0.1$ & $13.10 \pm 0.15$ & $9.38 \pm 0.2$ & $11.68 \pm 0.2$ & $11.76 \pm 0.48$ & $5.32 \pm 0.2$ \\
\hline Rate constant $\left(h^{-1}\right)$ & 0.101 & 0.152 & 0.109 & 0.135 & 0.136 & 0.060 \\
\hline \multicolumn{7}{|l|}{ K efflux (mmol) } \\
\hline liter of cells $\times h)$ & $24.24 \pm 1.2$ & $2.39 \pm 0.25$ & $25.34 \pm 0.2$ & $1.09 \pm 0.1$ & $6.06 \pm 0.25$ & $1.43 \pm 0.08$ \\
\hline Rate constant $\left(h^{-1}\right)$ & 0.269 & 0.026 & 0.281 & 0.012 & 0.077 & 0.015 \\
\hline \multicolumn{7}{|l|}{$\mathrm{K} / \mathrm{Na}$ efflux } \\
\hline Rate constant ratio & 2.7 & 0.17 & 2.6 & 0.09 & 0.57 & 0.25 \\
\hline
\end{tabular}

(A) $\mathrm{Na}$ influx into fresh cells was measured from media containing $140 \mathrm{mM} \mathrm{NaCl}$ (different $\mathrm{pH}$ ) and $100 \mathrm{mM} \mathrm{NaCl}$ (different osmolarities). $\mathrm{K}$ influx into fresh cells was measured from media containing $140 \mathrm{mM} \mathrm{NaCl}$ and $5 \mathrm{mM} \mathrm{KCl}$ (different $\mathrm{pH}$ ) and $100 \mathrm{mM} \mathrm{NaCl}$ and $5 \mathrm{mM} \mathrm{KCl}$ (different osmolarities). (B) Na efflux was measured into $140 \mathrm{mM}$ choline chloride medium from CC cells containing 86.2 and $7.2 \mathrm{mmol} / \mathrm{liter}$ of cells of $\mathrm{Na}$ and $\mathrm{K}$, respectively. $\mathrm{K}$ efflux was measured into $140 \mathrm{mM}$ choline chloride medium from fresh CC cells (5 and $90 \mathrm{mmol} / \mathrm{liter}$ of cells of $\mathrm{Na}$ and $\mathrm{K}$, respectively). Control experiments in AA cells were performed under similar conditions. The results are the mean $\pm \mathrm{SD}$ of two different determinations in the same CC patient and in two AA controls.

Table VII. Maximal Rates of Na-K Pump, Na-K Cotransport, and Na-Li Countertransport in CC and AA Erythrocytes

\begin{tabular}{|c|c|c|c|c|}
\hline \multirow[b]{2}{*}{ Cation } & \multicolumn{2}{|c|}{ Cellular content } & \multicolumn{2}{|l|}{ Flux } \\
\hline & $\mathrm{CC}$ & $\mathbf{A A}$ & $\mathrm{CC}$ & AA \\
\hline & \multicolumn{2}{|c|}{$\mathrm{mmol} / \mathrm{liter}$ of cells } & \multicolumn{2}{|c|}{ mmol/liter of cells $\times h$} \\
\hline $\mathrm{Na}$ & $44.4 \pm 4$ & $45 \pm 3$ & & \\
\hline $\mathbf{K}$ & $50 \pm 8$ & $53 \pm 7$ & & \\
\hline \multicolumn{5}{|c|}{ Na-K pump } \\
\hline Ouab & sitive $\mathbf{N a}$ & & $12.1 \pm 3.2$ & $4.9 \pm 0.9$ \\
\hline \multicolumn{5}{|c|}{ Na-K cotransport } \\
\hline \multirow{2}{*}{\multicolumn{3}{|c|}{$\begin{array}{l}\text { Bumetanide-sensitive } \mathrm{Na} \text { efflux } \\
\mathrm{K} \text { efflux }\end{array}$}} & $0.1 \pm 0.1$ & $1.1 \pm 0.35$ \\
\hline & & & $0.1 \pm 0.1$ & $1.2 \pm 0.35$ \\
\hline $\mathbf{N a}$ & $2 \pm 1$ & $2.5 \pm 2.0$ & & \\
\hline $\mathrm{Li}$ & $9.5 \pm 1.7$ & $7.5 \pm 1.0$ & & \\
\hline $\mathbf{K}$ & $78 \pm 2$ & $88 \pm 5.5$ & & \\
\hline \multicolumn{3}{|c|}{$\mathrm{Na}-\mathrm{Li}$ countertransport } & $0.56 \pm 0.1$ & $0.27 \pm 0.13$ \\
\hline
\end{tabular}

The intracellular $\mathrm{Na}$ and $\mathrm{K}$ content were reciprocally varied with the nystatinloading procedure. Na-K pump was measured as ouabain-sensitive $\mathrm{Na}$ efflux into $130 \mathrm{mM}$ choline and $10 \mathrm{mM} \mathrm{KCl}$ medium. Na-K cotransport was measured as bumetanide-sensitive $\mathrm{Na}$ and $\mathrm{K}$ efflux, in the presence of ouabain, into $140 \mathrm{mM}$ choline medium. $\mathrm{Na}-\mathrm{Li}$ countertransport was measured as $\mathrm{Li}$ efflux, in the presence of ouabain and bumetanide, into $140 \mathrm{mM}$ choline and $140 \mathrm{mM}$ $\mathrm{NaCl}$ media. All the media contained $1 \mathrm{mM} \mathrm{MgCl}, 10 \mathrm{mM}$ Tris-MOPS, $\mathrm{pH}$ 7.4 , at $37^{\circ} \mathrm{C}$, and $10 \mathrm{mM}$ glucose. The concentrations of the inhibitors were 0.1 $\mathrm{mM}$ for ouabain and $0.01 \mathrm{mM}$ for bumetanide. The results are the mean \pm standard deviation of three determinations in two CC subjects and in three AA controls.
CC cells is increased to the value observed in AA cells (by adding cell $\mathrm{K}$ through the nystatin method), the $\mathrm{CC}$ cells lose $K$ (and water) until they return to the cation content and volume that they display in vivo (Fig. 1, Table II). This response is not blocked by the simultaneous presence of $\mathrm{OB}$ and, therefore, apparently does not involve either the Na-K pump or $\mathrm{Na}-\mathrm{K}$ cotransport. This response occurs both when the cell $\mathrm{Na}$ is low in the absence of ouabain and when it is high in the presence of the glycoside (Table II). In the second case, the return of the cation content of the $\mathrm{CC}$ cells to the reduced value that they exhibit in vivo, involves a greater loss of $K$. The response is not the result of increasing $K$ content per se, in that it can also be initiated by swelling cells in hypotonic media (Fig. 2). Therefore, the response is produced by a direct or indirect effect of cell swelling. Because this response does not occur in AA cells, it apparently involves a OB-resistant $\mathrm{K}$ transport pathway that is active in $\mathrm{CC}$ but not in AA cells. This pathway does not seem to carry out $\mathrm{K} / \mathrm{K}$, $\mathrm{K} / \mathrm{H}$ (Fig. 6), or $\mathrm{K} / \mathrm{Na}$ (Figs. 3 and 5) exchange. It occurs even when the cell free $\mathrm{Ca}$ concentration is markedly reduced (Table IV) or in the presence of various inhibitors of the Ca-activated $K$ channel of the erythrocyte membrane first described by Gardos (5) (Table V). Therefore, it does not have the same activation and inhibition characteristics as the Ca-activated $\mathrm{K}$ channel. In contrast to what has been reported by others (15), our data do not support the hypothesis that the Ca-dependent pathway for $\mathrm{K}$ transport is the mechanism responsible for the reduction of $\mathrm{K}$ content of $\mathrm{CC}$ cells. 
This pathway for $\mathrm{K}$ movement in $\mathrm{CC}$ cells is regulated by cell volume and $\mathrm{pH}$. The interpretation of these effects is not clear because of the interactions between these variables. When internal $\mathrm{pH}$ is reduced at constant external $\mathrm{pH}$ (see Fig. 6), cell chloride concentration, $\mathrm{OH}^{-}$, and volume rise and membrane potential becomes more inside-positive. Sorting out the relative importance of these parameters will require further studies. It seems clear that the actions of $\mathrm{pH}$ and volume are partly additive, because swelling increases further the flux when $\mathrm{pH}_{\mathrm{i}}$ is at the optimum value (Fig. 7). However, the two effects are not completely independent because OB-resistant $\mathrm{K}$ efflux does not increase upon swelling of $\mathrm{CC}$ cells when the $\mathrm{pH}_{\mathrm{o}}$ is 8.0 or 6.5 (Fig. 7).

There have been many previous reports of volume-related $K$ transport pathways in several types of cells. Normal human (AA) erythrocytes have increased OB-resistant $\mathrm{K}$ transport when swollen under isosmotic conditions $\left(\mathrm{pH}_{\mathrm{o}} 7.4\right)$ by the nystatin method (9). However, the magnitude of the increase is substantially less than we have observed in CC cells (compare in Fig. 4), and is apparently insufficient to accomplish volume regulation over the time course required for this process in CC cells (Fig. 1).

Deoxygenation of erythrocytes containing only hemoglobin $\mathrm{S}$ (SS cells), has long been known to produce an increase in $\mathrm{Na}$ and $\mathrm{K}$ permeabilities (16). The increased $\mathrm{K}$ transport in de-oxygenated SS cells has more recently been shown to be resistant to ouabain and bumetanide (17). Roth et al. (18) showed that the deoxygenation-dependent $\mathrm{K}$ efflux from SS red cells, in the presence of ouabain, had the same $\mathrm{pH}$ dependence as in AA cells, and that it was inhibited by incubation in hyposmotic medium. In SC cells, the deoxygenation-induced $\mathrm{K}$ efflux is inhibited when the cells are swollen in hyposmotic medium (19). Clearly, hemoglobin polymerization plays a very important role in determining this behavior. It would be interesting to investigate whether oxygenated SS cells have a volume- and $\mathrm{pH}$-dependent $\mathrm{OB}-$ resistant $\mathrm{K}$ transport pathway similar to that which we have observed in $\mathrm{CC}$ cells.

Cala has described a volume-related $\mathrm{K}$ transport system in Amphiuma erythrocytes (20). This system apparently differs from the pathway that we have described in human $\mathrm{CC}$ red cells. The amphiuma system carries out $\mathrm{K} / \mathrm{H}$ exchange, coupled to the $\mathrm{Cl}^{-} / \mathrm{HCO}_{3}^{-}$exchange mechanism, and is activated by increasing the concentration of internal $\mathrm{Ca} \mathrm{(21).} \mathrm{None} \mathrm{of} \mathrm{these}$ properties are characteristics of the $\mathrm{CC}$ system. Volume-related $\mathrm{K}$ transport systems have also been reported in duck and other avian erythrocytes (22). These systems are inhibited by bumetanide and appear to involve $\mathrm{K} / \mathrm{K}$ exchange and a Na-K co-transport, again clearly different from the OB-resistant $\mathrm{K}$ transport pathway in $\mathrm{CC}$ cells reported in this paper.

Human lymphocytes also have a volume-related $\mathrm{K}$ transport pathway, which is resistant to $\mathrm{OB}(23)$. The volume regulatory response in lymphocytes also includes the opening of a $\mathrm{Cl}$ channel (24). The OB-resistant $K$ channel in lymphocytes differs from the pathway that we describe in CC cells in that it is activated by internal $\mathrm{Ca}$ and inhibited by quinine and calmodulin inhibitors (23).

The most interesting question raised by the observations reported in this paper is how a point mutation in the $\beta$-chain of hemoglobin can produce a change in cation transport across the erythrocyte membrane. If one makes the parsimonious and plausible assumption that the point mutation in globin is the only inherited genetic abnormality affecting CC red cells, it is likely that the abnormal globin interacts directly with the cation transport system or its regulators in such a way as to produce the observed transport abnormalities or with a membrane component not normally involved in cation transport. It has been shown that hemoglobin binds to the erythrocyte membrane $(25,26)$ and that hemoglobin $C$ binds with a higher affinity than hemoglobin $\mathrm{A}$ at neutral $\mathrm{pH}(27,28)$. An important site of interaction with the membrane is the $\mathrm{N}$-terminal segment of band 3 , which contains a sequence of 23 residues of which 14 are either glutamate or aspartate (29). This sequence contains no amino acids with positively charged side chains and thus constitutes an intensely negatively charged binding site for positively charged residues in hemoglobin and other molecules. The binding of hemoglobin A to the 23,000mol wt N-terminal segment of band 3 shows a bell-shaped dependence on $\mathrm{pH}$, with optimum binding occurring at $\mathrm{pH}$ 5.6-6.0 (29). The binding of hemoglobin $\mathrm{C}$ to band 3 persists at higher $\mathrm{pH}(7.0)$ (27).

It is plausible to postulate that the binding of hemoglobin $\mathrm{C}$ to band 3 activates the volume- and pH-dependent OBresistant $\mathrm{K}$ transport pathway that reduces the $\mathrm{K}$ content of $\mathrm{CC}$ red cells. The bell-shaped curve of dependence of $\mathrm{K}$ transport on $\mathrm{pH}$ (Fig. 5) can be interpreted to mean that increasing the intracellular proton concentration has at least two effects on the system. One might be to increase the binding of some activator, e.g., hemoglobin, and the other to titrate, and thus inhibit the transport system itself. Such a model could account for the failure of AA cells to display activation of $\mathrm{OB}$-resistant $\mathrm{K}$ transport with decreasing $\mathrm{pH}$. When the $\mathrm{pH}$ becomes low enough to produce the net charge on hemoglobin A necessary to promote binding to and activation of the transport system, the transport system may already be inhibited by direct titration.

This hypothesis is consistent with the recent proposal that band 3 is the locus of a K "leak" in human red cells (30), and earlier reports of interactions between monovalent anion and cation transport (31). It may also be related to the bell-shaped dependence of $\mathrm{Cl}$ transport through band 3 on $\mathrm{pH}$ (32). Certain relevant experimental findings cannot be easily accommodated by this model for $\mathrm{K}$ leak via hemoglobin-band 3 interaction. Cation transport is known to occur on band 3 in the form of ion pairs of hydroxyl acids, e.g., $\mathrm{NaCO}_{3}^{-}$(33). However, such ion pairs form to an appreciable extent with $\mathrm{Li}$ and $\mathrm{Na}$ but not with $\mathrm{K}$. Furthermore, such transport of $\mathrm{Li}$ and $\mathrm{Na}$ as anionic ion pairs on band 3 is inhibited by DIDS. The cation transport system that we have described in CC cells is selective for $\mathrm{K}$ and is not inhibited by DIDS.

Secondly, we have found significant differences in the maximal rates of the $\mathrm{Na}-\mathrm{K}$ pump, $\mathrm{Na}-\mathrm{K}$ cotransport, and $\mathrm{Na}-$ Li exchange between $\mathrm{CC}$ and AA cells (Table VII). The elevation in the $\mathrm{Na}-\mathrm{K}$ pump may be responsible for the reduced $\mathrm{Na}$ content of $\mathrm{CC}$ red cells. It is not clear to what extent the differences in these transport systems reflect the younger age of circulating CC cells (2-3\% reticulocytes) owing to the mild hemolytic anemia encountered in these patients. The abnormalities in these transport systems do not seem to be directly involved in producing the reduced $\mathrm{K}$ content of $\mathrm{CC}$ cells. Clearly, further research is necessary to elucidate the connection between the point mutation in $\beta$-globin and the cation transport characteristics of $\mathrm{CC}$ red cells. 


\section{Acknowledgments}

This work was supported by grant HL-34671 from the National Institutes of Health and by the Howard Hughes Medical Institute.

\section{References}

1. Bunn, H. F., and B. G. Forget. 1985. Hemoglobin: molecular, genetic and clinical aspects. W. B. Saunders Company, Philadelphia. In press.

2. Murphy, J. R. 1968. Hemoglobin CC disease: rheological properties of erythrocytes and abnormality in cell water. J. Clin. Invest. 47: 1483-1495.

3. Murphy, J. R. 1976. Hemoglobin CC erythrocytes: decreased intracellular $\mathrm{pH}$ and decreased $\mathrm{O}_{2}$ affinity-anemia. Semin. Hematol. 13:177-180.

4. Brugnara, C., A. Kopin, H. F. Bunn, and D. C. Tosteson. 1984. Electrolyte composition and equilibrium in hemoglobin $\mathrm{CC}$ red cells. Trans. Am. Assoc. Phys. In press.

5. Lew, V. L., and H. G. Ferreira. 1977. The effect of Ca on the $\mathrm{K}$ permeability of red cells. In Membrane Transport in Red Cells. J. C. Ellory and V. L. Lew, editors. Academic Press, Ltd., London. 93-100.

6. Brugnara, C., A. Kopin, H. F. Bunn, and D. C. Tosteson. 1984. Cation transport in hemoglobin CC red cells. J. Gen. Physiol. 84:33a. (Abstr.)

7. Freedman, J. C., and J. F. Hoffman. 1979. Ionic and osmotic equilibria of human red blood cells treated with nystatin. J. Gen. Physiol. 74:157-185.

8. Canessa, M., I. Bize, N. Adragna, and D. C. Tosteson. 1982. Cotransport of lithium and potassium in human red cells. J. Gen. Physiol. 80:149-168.

9. Adragna, N. C., and D. C. Tosteson. 1984. Effect of volume changes on ouabain-insensitive net outward cation movements in human red cells. J. Membr. Biol. 78:43-52.

10. Hladky, S. B., and T. J. Rink. 1977. pH equilibrium across red cell membrane. In Membrane Transport in Red Cells. J. C. Ellory and V. L. Lew, editors. Academic Press, Ltd., London. 115-135.

11. Milanick, M. A., and J. F. Hoffman. 1982. The separate effect of internal and external $\mathrm{pH}$ on cation influxes in human red blood cells as studied by means of a pH clamp. J. Gen. Physiol. 80:52a. (Abstr.)

12. Benos, D. J. 1982. Amiloride: a molecular probe of sodium transport in tissues and cells. Am. J. Physiol. 242:C131-C145.

13. Ferreira, H. G., and V. L. Lew. 1977. Passive Ca transport and cytoplasmic Ca buffering in intact red cells. In Membrane Transport in Red Cells. J. C. Ellory and V. L. Lew, editors. Academic Press, Ltd., London. 53-91.

14. Ellory, J. C., P. W. Flatman, and G. W. Stewart. 1983. Inhibition of human red cell sodium and potassium transport by divalent cations. J. Physiol. (Lond.). 340:1-17.

15. Berkowitz, L. R., C. Skrzynia, M. D. Rhoda, M. C. Garel, F. Galacteros, and Y. Benzard. 1983. Calcium sensitivity of the Gardos pathway in normal and hemoglobinopathic red cells. Blood. 62(Suppl. 1):34a. (Abstr.)

16. Tosteson, D. C., E. Carlsen, and E. T. Dunham. 1955. The effects of sickling on ion transport. I. Effect of sickling on potassium transport. J. Gen. Physiol. 39:31-53.

17. Joiner, C. H., O. Platt, and S. E. Lux. 1984. Abnormal sodium/ potassium exchange in the deoxygenated sickle red blood cells. Clin. Res. 32:497A. (Abstr.)

18. Roth, E. F., R. L. Nagel, and R. M. Bookchin. 1981. pH dependency of potassium efflux from sickled cells. Am. J. Hematol. 11:19-27.

19. Fabry, M. E., D. K. Kaul, C. Raventos-Suarez, H. Chang, and R. L. Nagel. 1982. SC erythrocytes have an abnormally high intracellular hemoglobin concentration. J. Clin. Invest. 70:1315-1319.

20. Cala, P. M. 1980. Volume regulation by Amphiuma red blood cells: the membrane potential and its implications regarding the nature of the ion-flux pathways. J. Gen. Physiol. 76:683-708.

21. Cala, P. 1983. Cell volume regulation by Amphiuma red blood cells: the role of $\mathrm{Ca}^{2+}$ as a modulator of alkali metal/ $\mathrm{H}^{+}$exchange. $J$. Gen. Physiol. 82:761-784.

22. Kregenow, F. M. 1981. Osmoregulatory salt transport mechanisms: control of cell volume in anisotonic media. Annu. Rev. Physiol. 43:493-505.

23. Grinstein, S., A. Dupre, and A. Rothstein. 1982. Volume regulation by human lymphocytes. Role of calcium. J. Gen. Physiol. 79:849-868.

24. Grinstein, S., C. A. Clarke, A. Dupre, and A. Rothstein. 1982. Volume-induced increase of anion permeability in human lymphocytes. J. Gen. Physiol. 80:801-823.

25. Shaklai, N., J. Yguerabide, and H. M. Ranney. 1977. Interaction of hemoglobin with red blood cell membranes as shown by a fluorescent chromophore. Biochemistry. 16:5585-5592.

26. Shaklai, N., J. Yguerabide, and H. M. Ranney. 1977. Classification and localization of hemoglobin binding sites on the red blood cell membrane. Biochemistry. 16:5593-5597.

27. Reiss, G. H., H. M. Ranney, and N. Shaklai. 1982. Association of hemoglobin C with erythrocyte ghosts. J. Clin. Invest. 70:946-952.

28. Friedman, M. J. 1981. Hemoglobin and the red cell membrane: increased binding of polymorphic hemoglobins and measurement of free radicals in the membrane. In The Red Cell: Fifth Ann Arbor conference. Alan R. Liss, Inc., New York. 519-531.

29. Kaul, R. K., and H. Köhler. 1983. Interaction of hemoglobin with Band 3: a review. Klin. Wochenschr. 61:831-837.

30. Lukacovic, M. L., M. R. Toon, and A. K. Solomon. 1984. Site of red cell cation leak induced by mercurial sulfhydryl reagents. Biochim. Biophys. Acta. 772:313-320.

31. Funder, J., and J. O. Wieth. 1967. Effects of some monovalent anions on fluxes of $\mathrm{Na}$ and $\mathrm{K}$, and on glucose metabolism of ouabain treated human red cells. Acta Physiol. Scand. 71:168-185.

32. Gunn, R. B., M. Dalmark, D. C. Tosteson, and J. O. Wieth. 1973. Characteristics of chloride transport in human red cells. J. Gen. Physiol. 61:185-206.

33. Funder, J., D. C. Tosteson, and J. O. Wieth. 1978. Effects of bicarbonate on lithium transport in human red cells. J. Gen. Physiol. 71:721-746. 